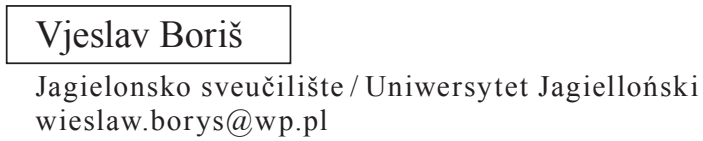

\footnotetext{
Wiesław Boryś

Jagiellonian University

wieslaw.borys@wp.pl
}

\title{
HRVATSKA DIJALEKATSKA IMENICA ZULO/ZJULO
}

\section{THE CROATIAN DIALECTAL NOUN ZULO/ZJULO}

U radu se razmatra porijeklo dijalekatske imenice zulo (zula, zjulo) 'otvor u peći'. Njen ishodišni oblik mogla je biti forma ženskoga roda *zbj-ula 'nešto otvoreno', izvedenica sufiksom -ula od psl. glagola *zbjati, *zĕjo 'biti otvoren, zijati, zijevati'. Oblici srednjega roda s nepotvrđenim sufiksom -ulo vjerojatno su sekundarni. Nije jasno zašto se u oblicima zula, zulo izgubio suglasnik $-j-$.

Ključne riječi: hrvatski jezik, narječje, imenica, etimologija, zulo/zjulo

In this paper the origin of the Croatian dialectal noun zulo (zula, zjulo) 'opening in the furnace' is discussed. Its initial form is supposed to have been the feminine gender noun $*_{z b j-u l a}$ 'something open', a derivative with the suffix -ula from the Proto-Slavic verb *zbjati, *zĕjo 'to be open, gape, yawn'. Neuter gender forms with the unattested suffix -ulo are probably secondary. It is not clear why the consonant $-j$ - is missing from the forms zula, zulo.

Keywords: Croatian language, dialect, noun, etymology, zulo/zjulo.

U hrvatskim narječjima postoji više leksema sa značenjem 'otvor u nečemu ili kroz nešto'. Glavni je, naravno, leksem rüpa, svojstven i standardnom jeziku, pored toga rapa (vjerojatno njegova dijalekatska varijanta) te niz drugih leksema: buža, luknja, prelo, škula/škulja (> škuja), šupljina, zjalo. Ove imenice i pokušaje objašnjenja njihove etimologije nalazimo u Etimologijskom rječniku hrvatskoga ili srpskoga jezika Petra Skoka. Međutim, u pomenutom rječniku ne nalazimo imenicu zulo s inačicama zjulo, zula. Objašnjenje porijekla ove imenice je zadatak članka.

Leksem u obliku zulo nalazimo u nekim kajkavskim govorima: zulo 'rupa ili ždrijelo na peći' u Zagorju (ARj XXIII 151), zũlo 'otvor u peći za loženje' u samoborskom govoru (Žegarac Peharnik 2003: 364), zūlö 'rupa, otvor; otvor u peći 
za loženje' u donjosutlanskom govoru (RKDI 564). Isti oblik imenice morao je postojati također kod Hrvata u Slovačkoj, jer je u hrvatskom govoru mjesta Hrvatski Grob zabilježena izvedenica sa sufiksom -ko: zúlko 'otvor u peći kojim se kontrolirao pečeni kruh' (Takač 2004: 200). Ranije je istu riječ iz Hrvatskog Groba zapisao A. Václavík koji je naveo tačnije objašnjenje imenice zulko „pulkruhovitý otvor v múre vedla otvora na chlieb, vyklenutý asi $15 \times 15 \mathrm{~cm}, \ldots$ ktorým sa svieti do pece na chlieb, aby sa v peci nepredržal" (Václavík 1925: 25).

U govorima gradišćanskih Hrvata postoji također oblik zjulo. U takvim govorima u Austriji (i u Mađarskoj?) nalazimo zjulo 'zjalo; ždrijelo; oduška (peći), Ofenloch, Loch im Backofen' (GHR 821), zjlu:lo 'jama, rupa, otvor u peći (Grube, Loch, Ofenloch)' (Palkovits 1987: 249). Isti je oblik zabilježen u Slovačkoj (u hrvatskim selima Devinská Nová Ves i Dúbrava): zjúlo 'otvor u peći' (u izvoru: 'otvor do peci, „„̌elesno”, místo v peci, kam se sází chléb', Vážný 1927: 421).

U rječniku Pavla Rittera Vitezovića, napisanom oko 1700. godine, nalazimo zjúlo i pećno zjulo 'otvor u peći ('praefurnium, orificium)' te zjulo u drugom, očito sekundarnom značenju, prenesenom na terenski objekt 'jarak, jaz (emissarium)' (Vitezović 2009: 1379).

Ista se riječ javlja u anatomskom leksiku. Najranije u Vitezovićevu rječniku, vjerojatno preuzeta iz tadašnje medicinske terminologije na kajkavskom području: zjulo 'otvor maternice (amphideum)', u istom značenju plodnično zjulo i zjulo od plodnice, pored toga guzično zjulo 'stražnjica (podex)' (Vitezović 2009: 1379). Posljednje značenje ima razmatrana imenica kod gradišćanskih Hrvata: zjulo 'rit, zadnjica' (GHR 821) i u ličkom govoru u obliku zúla pejor. 'rit, stražnjica' (Čuljat 2004: 298). Ovo značenje nedvojbeno potječe iz ranijeg 'otvor na kraju debelog crijeva, šupak, čmar'.

U ličkim govorima zapisani su ženski oblici razmatranih riječi: zúla 'rupa u kamenu, u nasipu, koju voda probije' (ARj XXIII 150) i gorepomenuta zúla 'stražnjica'.

Zagonetan je još jedan oblik razmatrane imenice: ždûlo 'otvor, ždrijelo, otvor peći' i 'ponor' u čakavsko-kajkavskom govoru u okolici Karlovca i Duge Rese (Perušić 1993: 175). Nije isključeno da je to preobrazovanje prvobitnog lika zjulo sa $\check{z} d$ - pod utjecajem istoznačne imenice $\check{z} d r e l o$ 'ždrijelo'.

U hrvatskim štokavskim govorima i u srpskom jeziku postoji formalno i semantički slična imenica zjälo 'otvor, ždrijelo' (ARj XXII 877 iz djela slavonskog pisca J. S. Reljkovića, slavonskih govora Otoka, Orahovice, iz Bosne), u hrvatskom rječniku I. B. Šamije zjälo ima značenja 'grotlo' i 'otvor rane nekog organa' (Šamija RJH 1778), u slavonskom narječju zjalo je 'otvor na krušnoj peći, dimnjaku, štaglju' (Jakšić 2003: 317), u ličkom govoru zjälo znači 'otvor za loženje na zidanoj peći koji nema vrata' (Čuljat 2004: 297); u beogradskom akademskom rječniku nalazimo više značenja iste riječi: 'usta, usni otvor, čeljust', 'otvor, ždrelo, grlo; šupljina, rupa', 'ponor, bezdan, ambis; krater, grotlo', 'otvor na sudu, grlić' (RSAN VII 47), slično u srpskom rječniku Matice srpske: zjälo 'usni otvor, čeljust', 'ždrelo, grlo; rupa', 'ponor, ambis, bezdan' i fraza prodavati zjäla 'besposličiti, zaludničiti’ (RSJ 435). Naravno, sva srpska značenja razvila su se iz prvobitnog 'otvor, rupa'. 
Etimologiju imenice zjälo objasnio je već P. Skok (iako je, za Vukom Karadžićem, naveo samo frazu prodavati zjäla). Prema njemu, to je izvedenica (,,apstraktum”) od glagola zjäti 'biti otvoren, zijati, zijevati' sa sufiksom -alo (Skok ER 3: 656).

Dijalekatske imenice zulo (zũlo, zūlö), zula, zjulo (z| $\bar{u} l o$ ) srodne su sa štokavskim zjälo, ali nisu se mogle razviti iz zjälo jer nema razvitka $a>\bar{u}$, bitna je također razlika u akcentuaciji ovih riječi. Sve pomenute imenica izvedene su od istog glagola zjäti, zjâm 'biti otvoren, zijati, zijevati' (ARj XXII 877-878), koji kontinuira praslavensko *zbjati, *zějo 'otvarati se, biti otvoren' (Skok ER 3: 655656, Boryś SE 739). Razlikuju se ipak po sufiksima: zjälo ima sufiks -alo, koji postoji i u drugim odglagolskim izvedenicama (npr. gudalo, Babić 1986: 270), ostale imenice ukazuju na inače nepotvrđen sufiks -ulo ili poznat nekim jezicima -ula (upor. Sławski 1974: 110). Moguće je, dakle, da je prvotni rod očuvan u ličkom obliku zula, a da je u drugim oblicima srednji rod postao sekundarno, po uzoru na neke nepoznate imenice tog roda.

Predpostavljam da su razmatrane riječi postale u rano, starohrvatsko vrijeme, kada je u južnoslavenskim jezicima još postojao poluglasnik i da je prvobitni oblik bio *zbj-ula sa značenjem 'nešto otvoreno'. Nije jasno zašto je u oblicima zula, zulo nestao suglasnik $-j-$.

\section{BIBLIOGRAFIJA I KRATICE}

ARj — Rječnik hrvatskoga ili srpskoga jezika. Na svijet izdaje Jugoslavenska akademija znanosti i umjetnosti. I-XXIII. Zagreb, 1880-1976.

Babić Stjepan. Tvorba riječi u hrvatskom jeziku. Nacrt za gramatiku. Zagreb: Jugoslavenska akademija znanosti i umjetnosti — Globus, 1986.

Boryś SE - Boryś Wiesław. Słownik etymologiczny języka polskiego. Kraków: Wydawnictwo Literackie, 2005.

Čuljat Marko. Ričnik ličke ikavice. Gospić: Lika press, 2004.

GHR - Gradišćanskohrvatsko-hrvatsko-nimški rječnik. Zagreb — Eisenstadt: Grafički zavod Hrvatske, 1991.

Jakšić Martin. Divanimo po slavonski. Zagreb: Pergamena, 2003.

Palkovits Elisabeth. Wortschatz des Burgenländischkroatischen. Wien: Verlag der Österreichischen Akademie der Wissenschaften, 1987.

Perušić Marinko. Rječnik čakavsko-kajkavskih govora karlovačkodugoreškog kraja. Karlovac: Radio Karlovac, 1993.

RKDI - Hanzir Štefica, Horvat Jasna, Jakolić Božica, Jozić Željko, Lončarić Mijo. Rječnik kajkavske donjosutlanske ikavice. Zagreb: Institut za hrvatski jezik i jezikoslovlje, 2015.

RSAN - Речник срӣскохрвайског̄ књижевног̄ и народног̄ језика. 1-21-. Београд: Српска академија наука и уметности - Институт за српски језик САНУ, 1959-2019-.

RSJ - Речник срйског̄a језика. Ред. Мирослав Николић. Нови Сад: Матица српска, 2007.

Skok ER — Skok Petar. Etimologijski rječnik hrvatskoga ili srpskoga jezika. Knj. 1-4. Zagreb: Jugoslavenska akademija znanosti i umjetnosti, 1971-1974.

Sławski Franciszek. „Zarys słowotwórstwa prasłowiańskiego“. Słownik prasłowiański. T. 1. Wrocław: Ossolineum, 1974: 43-141.

Šamija RJH - Šamija Ivan Branko. Rječnik jezika hrvatskoga. Zagreb: Društvo Lovrećana Zagreb, 2012.

Takač, Ferdinand. Rječnik sela Hrvatski Grob. Horvatansko-hrvatsko-slovački rječnik. Zagreb: Institut za hrvatski jezik i jezikoslovlje, 2004.

Václavík Antonín. Podunajská dedina v Československu. Bratislava: Vydavatel'ské Družstvo, 1925. 
Vážný Václav. „Čakavské nářečí v slovenském Podunajî”. Sbornik filozofické fakulty Univerzity Komenského v Bratislavě 5/47-2 (1927): 122-336.

Vitezović 2009 - Ritter Vitezović Pavao. Lexicon Latino-Illyricum. Svezak treći. Hrvatskolatinski rječnik. Priredile Nada Vajs, Zrnka Meštrović. Zagreb: ArTresor naklada — Institut za hrvatski jezik i jezikoslovlje, 2009.

Žegarac Peharnik Milan. Mali tematski rječnik samoborskoga kajkavskog govora. Samobor: Samoborfest, 2003.

\section{Веслав Борысь}

ХОРВАТСКОЕ ДИАЛЕКТНОЕ СУЩЕСТВИТЕЛЬНОЕ ZULO/ZJULO

\section{Резюме}

В статье рассматривается происхождение хорватского диалектного существительного zulo (zula, zjulo) 'отверстие в печи'. Оно сопоставляется с однозначным штокавским существительным zjälo (также в значении 'рот, пасть, дыра, пропасть, бездна'), производным от глагола zjäti, zjâm 'зиять', который исходит из прасл. *zbjati, *zёjo 'открываться, быть открытым'. Исходной формой хорв. диал. zulo (zula, zjulo) могла быть форма женского рода *zbj-ula 'что-то открытое' (формы среднего рода вторичны), но остается неясным изчезновение согласного -j- в формах zula, zulo.

Ключевые слова: хорватский язык, диалект, существительное, этимология, zulo/zjulo. 